\title{
Meeting the educational challenges to engage veterinarians in animal welfare science Adroaldo Jose Zanella
}

\author{
Address: Department of Production Animal Clinical Sciences, Norwegian School of Veterinary Science, Ullevålsveien, 72, P.O. Box 8146 Dep., NO- \\ 0033 Oslo, Norway \\ Email: Adroaldo Jose Zanella - adroaldo.zanella@veths.no
}

from The role of the veterinarian in animal welfare. Animal welfare: too much or too little? The 2 Ist Symposium of the Nordic Committee for Veterinary Scientific Cooperation (NKVet)

Værløse, Denmark. 24-25 September 2007

Published: 19 August 2008

Acta Veterinaria Scandinavica 2008, 50(SuppI I):S4 doi:I0.1I86/I75I-0147-50-SI-S4

This abstract is available from: http://www.actavetscand.com/content/50/SI/S4

(c) 2008 Zanella; licensee BioMed Central Ltd.

\section{Background}

Animal welfare research programs are seldom integrated into the mainstream activities carried out in schools of veterinary science. Our goal at the Norwegian School of Veterinary Science (NVH) is to fully integrate our animal welfare research program with the training of veterinary students and with the regular activities carried out at the school. In my previous team we successfully developed a novel paradigm to teach animal welfare [1]. We harnessed a well-established and culturally accepted livestock judging model in order to minimize the bias resulting from an inherent polarized and politicized view of animal welfare in the USA [1]. The animal welfare judging/assessment competition has revolutionized teaching of animal welfare in some animal science departments in the USA [1]. In my previous team we expanded the concept of virtual environments to enhance learning animal welfare related topics through an on-line teaching program using interactive media $[2,3]$.

\section{Materials and methods}

At the Norwegian School of Veterinary Science, in Oslo, we are attempting to integrate our animal welfare research program using four complementary ways: 1) At the NVH we designed the animal welfare laboratory with capability to offer services to the NVH community. We are equipped to collect real time video data on activity levels, via computer tracking software, on animals kept in our teaching hospital including animals kept in surgical recovery rooms. 2) Secondly, we are discussing with our team of clinicians, working at the NVH companion animal hospital, at the NVH ambulatory and stationary clinics, ways to develop pain assessment protocols. It is our goal to create a comprehensive video-library of pain related conditions and associated criteria to, subjectively and objectively, assess animal pain and to teach pain assessment to students. 3) Thirdly we were the recipient of a grant in collaboration with Iowa State University, USA, and the University of Guelph, Canada, to organize a workshop exploring the relationship between epidemiology and animal welfare. 4) Lastly, our graduate students interact in an effective way with the NVH community through clinical work, seminars, brown bag lunch discussions and research projects.

\section{Results and discussion}

We are using cutting edge interactive media, including virtual reality environments, to create experiential learning opportunities comparable to real life exposure. We obtained extramural funds to explore the role of epidemiological studies in animal welfare assessment protocols. Three of the Ph.D. students enrolled at the NVH animal welfare program are conducting picture and movie based surveys to assess attitudes toward pain among stakeholders. We also are involved in Nordic initiatives to optimize the use of resources to teach animal welfare science. It is our long-term goal to develop collaborative protocols with higher education institutions, official veterinary services or governmental organizations to monitor the practical aspects of evaluating the impact of training protocols. 
Ultimately, by combining foundational online courses with modules on more advanced topics, online certificates and graduate programs in animal welfare could be established to benefit students nationally and internationally.

\section{References}

I. Heleski CR, Zanella AJ, Pajor E: Animal welfare judging teams a way to interface welfare science with traditional animal science curricula? Applied Animal Behaviour Science 2003, 81:279-289.

2. Siegford JM, Bernardo TM, Malinowski RP, Laughlin K, Zanella AJ: Integrating animal welfare into veterinary education: using an online, interactive course. I Vet Med Educ 2005, 32(4):497-504.

3. Siegford JM, Zanella AJ, Bernardo T, Wickens C, Laughlin K, Malinowski R: Leveraging expertise in animal welfare to create educational equity. Animal Welfare 2007, 16:24I-243.

Publish with Bio Med Central and every scientist can read your work free of charge

"BioMed Central will be the most significant development for disseminating the results of biomedical research in our lifetime."

Sir Paul Nurse, Cancer Research UK

Your research papers will be:

- available free of charge to the entire biomedical community

- peer reviewed and published immediately upon acceptance

- cited in PubMed and archived on PubMed Central

- yours - you keep the copyright

Submit your manuscript here:

http://www.biomedcentral.com/info/publishing_adv.asp 